\title{
2. Sibyl and the Crazed Painting
}

\begin{abstract}
This chapter delves into the character of Sibyl in Oscar Wilde's novel The Picture of Dorian Gray. Her temporally-fickle, doomed romance with Dorian is analyzed in relation to her timeless, perdurable connection with artistry and tragedy. The chapter traces Sibyl's vacillation between repudiation and transgression, between presence and absence. The gender-specific consequences of loving and losing are explored against the backdrop of an entrapped woman-spectacle seeking the depth and directionlessness of timeless art and romance.
\end{abstract}

Keywords: Love-malady, Woman in love, Tragic Romance, Timeless Art, Caged Spectacle

Sibyl is a doomed soul. The very fact that her existence always fails to synchronize with the linearities of time establishes her inheritance of a wounded temporality. Oscar Wilde's The Picture of Dorian Gray dissects the artistic monopoly of this seemingly peripheral woman and discovers a senile mole/stone. This woman who lives many lives rolled into one is too omnipresent a symbol of passion and ferocity. Her character foreshadows all that can remain unchanged within a static cage of narcissistic simulation despite its seeming outward changes and distortions.

This chapter will centre around Sibyl Vane, the romantic interest of Dorian Gray, Wilde's protagonist in The Picture of Dorian Gray (189o). The romance between Dorian and Sibyl is unable to come to fruition because Dorian fails to love Sibyl beyond the art she personifies in the characters of the Shakespearean heroines she enacts on the stage. Her suicide, after having been spurned by Dorian, is only the beginning of her struggles with temporality and its changing facets.

Sibyl is the nemesis of Dorian; she is the antithetical art to Dorian's. Dorian sees her as a mesmerizing actress whose acting genius and enthralling beauty serve to fill up the void of timelessness and spacelessness that he

Ahlawat. I., Women and Temporality in Literature and Cinema: Negotiating with Timelessness. Amsterdam: Amsterdam University Press DOI 10.5117/9789463729741_CHO2 
has been vying for and that he perceives as the hallmark of happiness and gratification. She is one of those 'sentimental people' (Wilde, 1991: 40) that he is so fond of exploiting. Her sentimentality makes her want to 'attach' herself, whereas Dorian's sentimentality drives him more and more towards detachment; this, despite Sibyl having had hardly any concrete society and Dorian having had much of it. Sibyl seems to have quite perfected the art of attaching herself even to art and its manifestations, while Dorian enjoys the sport of detachment.

Sibyl and her existence and her art represent Dorian's veering towards a parallel reality; she is the initiating push of his 'wild desire to know everything about life' (40). Dorian takes on 'the search for beauty' (41) and makes it the ultimate quest for a real life. Sibyl becomes his first full-fledged encounter and impression with beauty. The various parts of her beauty represent both life as well as death, in varying proportions, while some parts overlap with both life and death. Dorian loves the parts of her that ooze out death, tragedy and their overwhelming cathartic beauty. He is in love with the 'grande passion' (41) that comes with the colour of too much longing and the ennui of death.

Sibyl, then, is Dorian's 'greatest romance' (41) and his greatest failure. She was born as art, lived as art and, just when she began to touch the base, mundane world, her body and soul revolted against the tide of reality that, by virtue of its limitations and measurability, had the ability to entrap her in time and space. Says Henry of her, 'The moment she touched actual life, she marred it, and it marred her' (84).

Her acting is her existence in all its catharsis, and her catharsis is the refuge of the failure-parched souls like Dorian's. She is to Dorian both beauty and pathos - imagination and fatality - a fetishized idealization of distance and illusion. Dorian says of her to Henry, 'She is everything to me in life' (43). Dorian deifies art and its deathly aura, its enamour of omniscience and its weight of lingering. She is like death; everything till death finally arrives in all its grandeur and horror and leaves with longing and failure, failing eventually to hold relevance.

Wilde says of Dorian, 'His sudden mad love for Sibyl Vane was a psychological phenomenon of no small interest. There was no doubt that curiosity had much to do with it, curiosity and the desire for new experiences; yet it was not a simple but rather a very complex passion.' (49). Sibyl is an actress who lives and rehearses with Shakespeare more than she lives in her own age and time. Like Virginia Woolf's Mrs. Dalloway, she has the inimitable gift '[...] to be. To sum it all up in the moment' (Woolf 1953: 174). She is Juliet, she is Rosalind, she is Imogen, she is Ophelia, and so on. She traverses time 
like the future belonged to her, and it was only the past she had to conquer. She draws curiosity and desire from Dorian because she is not limited to any particular phase of time or art; she is not 'limited to their century' (Wilde 1991: 43). Dorian envisions in her a sacred temporal goddess that may complement his strongest zeal to decode time. And, like Dorian, she has ingrained within her the potent seeds of narcissism.

Dorian comes to know of his power when Basil etches him in that wondrous painting. Let us, for instance, sample the lines Wilde uses for Dorian's first encounter with Basil's masterpiece, 'A look of joy came into his eyes, as if he had recognized himself for the first time [...] The sense of his own beauty came on him like a revelation' (23). The analogy with Sibyl becomes manifest when she falls in love with Dorian. For a brief while, she forgets that she is stronger than any time; instead she wishes to, like Dorian, confine herself to a perceived temporal perfection. Just as Basil becomes Dorian's nemesis, Dorian becomes hers. According to Dorian, 'she seemed quite unconscious of her power' (44). He also realizes that he must 'get her out of the Jew's hands' (45); it is almost as good as getting her out of time's hands. In his attempts at re-carving out her personality, Dorian is seeking to break her away from her Mirror stage (in Lacanian terms); although it also must be noted that because he himself has no established connection with the Symbolic, he abandons her over the doorstep of the Symbolic and rushes to redeem his own mighty Ego hurtling towards fast disseminating mirror images of his own.

Patrick Duggan, in his essay 'The Conflict Between Aestheticism and Morality in Oscar Wilde's The Picture of Dorian Gray', has harked back to mythology to posit how Dorian seems to have inherited terrifyingly close traits from Narcissus who, upon catching his glimpse in the pool became so 'enraptured by it that he stood and admired it endlessly, unmoving for the rest of his life' (2009). Dorian has a more serious dilemma. If there has to be a movement in time and space, he would rather that the painting takes its after-effects. In doing so, I contend, he chooses to really abandon timelessness for a bit of time-bound seasonal vulgarity. Unlike Sibyl, he eventually fails to comprehend the consequential truth that aestheticism is what prolongs time. Instead of transferring his aesthetic energies into the art he apparently eulogies in his facade of a connoisseur, he instead ends up bargaining his time for a fleeting trope of a spectacle. The longevity that he longs for is actually frittered away by him in choosing to maintain distance with art and aspiring to admire it from a distance. In his blind following of Henry's epigrams, he is unable to learn that it is only through an infatuated immersion in art, a direct confrontation with its fatality, can he possibly redeem his quest for eternity. 
Sibyl, on the other hand, 'knows nothing of life' (1991: 45). As Desdemona, Ophelia and other larger-than-life fictional heroines, she inhabits the realms of art. And, her eternal power lay in her ability to convince her audience of her higher aesthetic existence. Not only is she aware of her artistic superiority and immortality, but so are others who watch her and imagine her life. In other words, she is, for both herself and others, a living embodiment of artistic eternity and non-corrosive beauty. Dorian echoes the sentiments of all her spectators, 'She is all the great heroines of the world in one. She is more than an individual' (45).

According to Luce Irigaray in This Sex Which is Not One, women are perceived in society as market commodities who must be exchanged in order to escape from anarchy. In a way, anarchy is sublime art. Escaping from anarchy is also a step towards escaping art and its aesthetic candour. As per Irigaray, "The production of women, signs and commodities is always referred back to men (when a man buys a girl, he "pays" a father or a brother, not the mother [...], and they always pass from one man to another' (1977: 171). This is one major reason that Dorian is later miffed with Sibyl who chooses to not remain the product of her spectator's reifying interest; it is also the reason why James Vane disapproves of Sibyl herself aligning her sentimentalities with the peering eye of a spectator, and later wants to finish off the vestiges of his sister that Dorian snatches from him without paying necessary market obeisance (Vane attempts, unsuccessfully, to kill Dorian as a revenge). And, in the same vein, Dorian is afraid of James Vane, for he knows he had not followed procedure.

Sibyl is perceived as an expensive entity in the traffic of art and sexuality. Her 'reproductive use value' (Irigaray 1977:173) is that of encouraging the most hardcore and romanticized brands of heterosexuality. In being perceived as reproducing the artistic, cultural and social value of the characters of Juliet, Rosalind, Desdemona, she is one of those ideal commodities which, in all their heterosexual perfection and voyeurism-promoting artistic grandeur, are the bolstering signs of this economy of desire on theatre and art circles. Yet, they have no individual value on their own. It is the underwriters like the theatre manager, the Jew, who really presume to be controlling such commodities and their circulation.

As discussed earlier in this chapter, getting her out of the Jew's hands is as good as attempting to get her out of time's hands. Getting her out of the Jew's hands is like severing her from temporality and introducing her to masculine materiality. But, as she progresses in her playacting in life, Sibyl wants neither the narrow temporality that her theatre seeks to 
confine her into nor the monogamous materiality that Dorian seeks to drive her into.

Nevertheless, the beginning of the romance, the severance is a blur; in her 'prison of passion' (Wilde 1991: 50), she feels free temporarily - feels the 'joy of a caged bird' (50). She finds herself as a prized commodity in the market. For a while, she wants to circulate and be sold to a static temporal and masculine zone. However, her sado-masochism, just like every artistic piece exemplifying the sublime sacrifice of death, soon finds this too suffocating. The stasis and artistic decay that Dorian's belongings, his lifestyle and his treatment of everything beautiful exemplify soon comes across as disillusionment to Sibyl. James' words, 'He wants to enslave you' (56) come ringing to her rising consciousness of her losing monopoly over Shakespeare's beautiful heroines. Her confession to Dorian later, "The painted scenes were my world. I knew nothing but shadows [...]', is strangely the concrete fabric of her extraordinary and time and space-traversing existence.

Dorian's rebuttal of her deteriorating influence over the market space is something she had deliberately desired initially, in the blindness of her real, straitjacketed perusal of love and idol-worship. She revels in the thought of being scorned, worshipped, explored and thrown. As Wilde puts of her, 'A faint blush, like the shadow of a rose in a mirror of silver, came to her cheeks as she glanced at the crowded enthusiastic house'(67). Like the painting of sorrow, Dorian, she too begins to see herself in the midst of the crowd, the marketplace that scrutinizes and passes judgments on her. In other words, her existence is then passed on to the spectators, instead of being the sole prerogative of her individual understanding.

In his book The Imaginary Signifier, Christian Metz has contended as follows on the subject of spectator-spectacle dynamics in a film:

Thus film is like the mirror. But it differs from the primordial mirror in one essential point: although, as in the latter, everything may come to be projected there is one thing and one thing only that is never reflected in it: the spectator's own body. In a certain replacement, the mirror suddenly becomes clear glass. (1982: 46$)$

This is how the spectator practices disempowerment upon the object in the marketplace - the wondrous actress, Sibyl. When blinded and in love, she is the clear glass that happily takes on projection but is unwilling to go that extra sacrificial distance to become the powerful mirror. The audience is happy that it can project and exchange in this marketplace of time, space, 
image, and gaze, and, in doing so, it need not constitute its own fallacies in the scheme of theatre objects.

Yet, this act of seeking disempowerment upon a distant object is also tantamount to being excluded from the beauty and fluidity of art and time. In other words, the powerlessness that Sibyl imposes upon herself is analogous and simultaneous with the powerlessness and impotence that the audience impose upon themselves. And, unlike a film, the human-ness' that the theatre embodies and reflects also does not add up to the establishment of any concrete attachment or socialization. It is convenient to be looking through a glass and discovering a sensually-appealing amalgam of narration and beauty.

In such a state, it is important for a spectator like Dorian to introspect upon the visual ground he stands on. Apparently, he goes to the theatre not for 'human-ness' but for a more transcendental version of solitariness. From the outset, he wishes for distance and imposes distance; very much like the distance he imposes upon the painting by Basil Hallward. The painting begins to appear flawed to Dorian with the growing passage of time and sin in his soul. With the overlapping of his deeds on the painting, the distance begins to diminish. Similarly, Sibyl, in her blind perusal of love, forgets her timelessness for a while, thereby generating in Dorian a similar scorn and repulsion that the painting generates in him.

One can even further contend that there seems to be a deeper psychoaesthetic connection between the painting and Sibyl. They are both breathtakingly beautiful and flawless, and they both embody the warmth and splendour of everlasting repeatability. Hence, they also manifest within themselves the sublime travesty to attach to the persona of Dorian, to fall for his fallibility. They both do so by taking upon themselves the vile detachments and the self-destructive spurnings of Dorian. Having served as the agents of artistic providence and having instilled in him the seeds of individualism, they both go on to bear Dorian's wrath of over-consumption and too little generation.

Sibyl's tragedy is passed on to Dorian through the painting, which comes to know of it and feel it directly from Sibyl's soul, and well before Dorian does. He is seen musing on it, 'It had received the news of Sibyl Vane's death before he had known of it himself' (1991: 85). In other words, the frustration and dejection of Dorian's infertility and inaction are borne by his most loving and most hated companions, Sibyl and Basil's painting. Dorian tells Basil at a certain point in the novel, 'There is something fatal about a portrait. It has a life of its own' (94).

The act of watching Sibyl from a distance is an expression of Dorian acting like a typical patriarchal spectator. As a matter of fact, he aspires to leap 
further in this role and become a 'spectacle dictator' (my term, as I choose to refer to it). In his aspirations as a spectacle dictator, he is seen making repeated and existentially desperate attempts at controlling the action, the actors and even their perception. This is to say that Sibyl is not love for him; instead she is the manifestation of love. The difference lies in her either carrying an essence of love within or carrying the nomenclature of love and its recitation in literature and in death. For him, Sibyl is the latter. Hence, it becomes unbearable for him to watch Sibyl making attempts to transgress the name and become love from within. He is heard telling her, 'You have spoiled the romance of my life [...] Without your art you are nothing' (71). In Sibyl too, he desires to harness and continue the aestheticism of tragedy and non-fulfilment- 'Like the painting of a sorrow,/A face without a heart' (170). Dorian's predicament revels in the illusion of perfection of art; he rejects the perfection of reality, for that is too close for comfort. However, his conception of 'perfection' is not moral and aesthetic purity; instead it is the anarchy and turbulence of corruption, degradation and death.

The question also arises as to why the painting and Sibyl take it upon themselves to fulfil the romantic fatality Dorian enforces upon them. It is a subject of extreme intrigue as to why destiny unfolds the way it does for Dorian. One must consider that Sibyl inherits the sacrificial altar of Shakespearean heroines and her conscious comes draped in the colours of scarlet - the colour of love, grotesquery, passion, betrayal, art, death. The narcissist Dorian mentions how his special attention towards her propels her also towards narcissism - someone who is aware of her power, her ability to cast an influence, often a spell, as a piece of art. Her romantic destiny is, therefore, intricately bound to a corresponding unfolding of tragedy that has its basis in locating her in the whirlwind of a tragic time, scrambling hard for certain, identifiable origins and prudence-centric narratives; revelling well in the rounded manifestation of the intense impulse of the present flanked by the vindictiveness of the past and the calamity of the future.

In choosing to bear the brunt of Dorian's material idiosyncrasies, both the painting and Sibyl are prolonging themselves in the bandwidth of time, veering towards self-awareness and self-advancement in the transcendental zone of space and time consciousness. Both Sibyl and the painting embody the eternity of art. Therefore, they can easily travel back and forth in time. Dorian, having given up on his art for a pretty reflecting illusion in the glass, cannot ever succeed in controlling the flow of time. The bitter truth of his 'nebulous existence' (as I could call it) is that he can neither mould the past nor influence the future; his present is anyway an escapist manifesto of 
momentous living. His present cannot and would not look at either of the directions - the future or the past.

In a discussion on Stendhal's Red and Black in his essay entitled 'Stendhal and Time', George Poulet has argued how living solely in the present is the key to happiness. One can further conclude that anyone who abandons the incoming and outgoing pangs of time for the stasis and jouissance of the present, then, must be the hopeful soul who is not, in the true sense, ambitious enough for his posterity or for the agelessness of his soul. In Poulet's terms, the ambition that renounces the ambition of a future or a consciousness of a past is an ambition that derives its driving power from the sentiments of a present action and immediate satiation. He comments, 'In short, the person who renounces the life of ambition gives up consciousness of his life in the form of the past as in the form of the future. And, suddenly, his life becomes a life without past or future. It is a life reduced to the present, a merely momentary life' (1969:471). Dorian's is such a pitiable life, with his swords down and ambition gone. Dorian, in a sense, perceives happiness in the present and is, therefore, continually bored of it and seeking more and more of it.

Sibyl, on the other hand, is Janus faced - she looks towards the past as well as towards the future. Despite her being confined to the theatre set-up that refuses to let her go, her vision looks in both the directions of time. She is ambitious and wants to feed her head with art over and above life. No wonder then that Dorian idolizes her entrapped being, for in her limited spatial being, she personifies for him the 'strange legacies of thought and passion, and whose very flesh was tainted with the monstrous maladies of the dead' (1991: 114). Sibyl herself admits to being enamoured of love and, for her, 'To be in love is to surpass oneself' (55). And, when Sibyl falls for that fleeting amount of present time in love, she begins to mistake this 'fall' (from grace) as yet another form of art she has been chosen to live and reproduce. In that time, she begins to long for the poison of mortality, much like Eve did. However, unlike Eve, she has had a much more fertile past; the legacies of thought and passion make her to leap back to art, this time with a much more immense force - in her narrative-friendly death. Eve could not survive in her present for she had no past to refer back to, and Sibyl could not survive for she boasted of a past beyond momentary borders and had a vision that foresaw art beyond death.

Henry says to Dorian of her death, 'The girl never really lived, and so she never really died' (83-84). In embracing death, Sibyl embraces art. It is in her death that she is able to perform for Dorian 'the supreme reality of Love' (85). In driving Sibyl to take away her own life, in choosing to take away beauty 
from Basil's painting, Dorian is really surrendering his share of eternity. In choosing death, Sibyl opts for art, while Dorian opts for life in choosing for mortal and base pleasures. On introspection some time later, it does look like a petty deal, after all, and not the grandiose bargain with the devil Henry makes it out to be. Sibyl, on the other hand, does come across as a real deal-clincher. James Vane's fears of Dorian's intentions of 'enslaving' Sibyl (without, of course, paying the necessary price to her original 'guardian', her brother) do turn out to be vain and unsubstantiated.

Sibyl's being surpasses time and the rosy pictures of its present. She is the renaissance, she is Eve reborn - only wiser; she is Webster's grotesquerie, she is Shakespeare's romance, she is Browning's monologues-inflicted tragedy, she is winter. To Dorian, she had been and, therefore, she must continue to remain a distant dream of a grand purity and a grand taint, a thing that continues...inspires awe, fear and pity, all simultaneously, like the deified epitome of sublimity.

She is quite like T.S. Eliot's the Sibyl. Wilde perhaps had consciously or subconsciously induced this post-structuralist motif in according to his heroine (and, she undoubtedly is the heroine of the novel) the name Sibyl. She serves as the modern reincarnation of the mythological character of the Sibyl who had it in her destiny to wage a relentless struggle waged at the ennui and temporal bindings of existence. Eliot's the Sibyl is entrapped in a cage and Wilde's Sibyl Vane is entrapped in a theatre set-up. Like Eliot's the Sibyl, Wilde's Sibyl is also entrapped in a delicate consciousness of art and the passage of time. They both have had the misfortune of being seduced in the name of love and lust too early in their lives. They both saw the prospect of attaining love and art through the means of passing through a man. They both were lured into giving up their sexuality and their exclusive monopoly over art - body as art, performance as art - to chauvinistic, self-motivated, lecherous predators. And, both the Sibyls suffered through betrayal, broken promises and false love and hope from their violators.

The onus of repentance for the acts of sexual transgression committed by Apollo and the Sibyl, Dorian and Sibyl Vane were borne by only the women while the men went about their hedonistic businesses as usual with absolutely no thought for the women they had 'turned' forever. It is as if the altar of sacrifice in time and in blood was being prepared by both Apollo and Dorian right from the beginning when they ventured into the vile cause of tainting the innocence of these two very young women who had not yet tasted the perversities of the world. The altar was to serve for both the men as the prison house that could entrap their victims in the impulse of the moment forever, while free the men from the corroding strokes of 
time. Of course, we do know the prisons did not exactly serve the purpose they were originally meant to serve.

Like Eliot's the Sibyl, Wilde's Sibyl also refuses to remain confined in Dorian's limited world. In choosing to rebel against their perpetrators of humiliation, they both take upon themselves independence and autonomy over their life choices, in spite of all the stigma, agony and struggle. Like Apollo, Dorian promises Sibyl Vane a world of eternal love and carnality, but soon she realizes that Dorian's is a world of momentary mortality and no ambition or vision for the future. Eventually, while one of the women daringly braves life, the other one braves death, and thus both keep the narrative going - in time, with time, ahead of time.

On Sibyl Vane's death, Henry tells Dorian to steer clear of reminiscences of living female souls; in their living, they go on to kill love. He gruntingly tells him of his encounters with these, "That awful memory of woman! What a fearful thing it is!' (82). The memory of a woman is truly an awful thing to happen to a man; it certainly must be feared. Her power to recount, blur, merge, foresee, 'forewish' (my term) are beyond the understanding of most egotistical, self-appraising men. Eliot's the Sibyl foresees and Wilde's Sibyl forewishes. Luce Irigaray, in This Sex Which is Not One, talks of Alice from Wonderland. She talks of Alice and another character Lucien's love in her book as a relationship that lies in the 'zone of "not yet". Or "never".' (1977: 11). Sibyl Vane's relationship with Dorian also lies in a similar zone of 'not yet' or 'never'. Like Alice's 'violet, violated eyes' (10), she too lives through the anxiety of inconsequent past dreams and sterile future nightmares. Her tryst with glasses do make her realize that 'Past and future both seem subject to quite a few risks' (11). In oscillating between the past and the future, between the dingy room and theatre, Sibyl really oscillates between the virgin and the whore. Dorian's contact and connection with her is never complete. He is either behind her in the 'not yet' zone or he has ventured too far on his own - alone - in the 'never' zone.

The truth is that Sibyl Vane is not looking for temporal and spatial fulfilment. She is, instead, craving for expansive meditations on timeless romances and tragedies unfolding through the lens of memories and perception. Irigaray says of Alice, 'She disappears into nature. Is it Saturday or Sunday?' (1977: 11). Like Alice, Sibyl is outside time, which is fluid and inter-dispersible. She may effortlessly flow into nature and vice versa. Dorian, on the other hand, is limited in his temporal and, therefore, functional base. He is confused mostly, 'Is it time for surveying or love?' (11), for he can only do one at a time. Surveying, like for most mortal, time-bound humans, is easy but transient, and gives joy and satisfaction and a feeling 
of completion of experience in the moment; love is way more difficult and beyond moments.

'To become the spectator of one's own life, as Harry says, is to escape the suffering of life' (1991: 89). The function of love is different from that of surveying. The fact that love is more inaccessible is also the reason why love may never be bought with just sound and performance, but may certainly be played through with vision and perception and manifestation. Love is different from surveying - they both contradict and divide each other; surveying renders one (subject) helpless while the other powerful. For instance, Sibyl, in the words of Irigaray in a different context, is subject to, at least in his limited concoction of the relationship, to the 'masculine specula(riza)tion' (1977:30) of Dorian. Love renders both powerful but both also become subject to another form of bondage - that of equality. 'The division of labour prevents them from making love' (28), says Irigaray of a man and woman's relationship. Dorian is incapable of love, for he does not, and cannot, envisage equality between himself and Sibyl. Also, because loving is for the romantics, who insist on 'digging up the past, and raking up the future' (1991: 82), and in the words of Henry who warns him from time to time, 'That is always a dreadful moment. It fills one with the terror of eternity' (82). And, someone who cannot imagine eternity with love cannot really imagine eternity with art and cannot, therefore, live eternity.

The remorse that Dorian feels the day after that fateful theatre night when he spurned her is only a momentary and superficial emotion, just like the first fleeting remorse he had on seeing his bared soul creeping towards decay in Basil's painting. It goes as quickly as it comes. When questioned by Basil for his ability to traverse emotions with such speed, Dorian retorts, 'What has the actual lapse of time got to do with it? It is only shallow people who require years to get rid of an emotion. A man who is master of himself can end a sorrow as early as he can invent a pleasure' $(87-88)$. It is actually like he is in a hurry to move ahead of time, rather than actually trying to prolong it. Or, perhaps, he is searching to feel unprecedented emotions and experiences within as little time as possible. The most plausible reason for his failure at this is the art that he unlearnt in this process, and that his nemesis, Sibyl learnt with every passing performance and theatrical scholarship she acquired across time. It also seems that he is intent on shortening the lifespan of everything that is artistic and beautiful around him - love, tragedy, mystery - and yet hopes to acquire the artistry and longevity that only an aesthete can conjure and imagine.

Sibyl is the time-traveller whose amorphous origins engrave her within the living systems of every era and within the impressionability of every 
man who may aspire for even the remotest of controls over the specular entropy of such eras. Yet, the entropy, vacillating, as it were, back and forth between innocence and experience has a stability of its own that is not dependent upon the time-bound and egoism-dictated patriarchs of the day. Sibyl shows how pleasure and hedonism are pitched against time and truth. Sibyl, like the force of tragedy, must strike again and again in every age and time-lapses with a conscience of cathartic judgments. Her female consciousness sentimentalizes and beatifies the scenes she brings to life. Long after her death, Dorian too is once again acquainted with Sibyl's being right after he murders Basil. Like the stroke of a timeless tragedy, he is reminded of Sibyl's selfless love in Basil's body. Stepping in his balcony right after bleeding the life out of Basil's body, he sees a crimson spot in the street corner and then sees that 'A woman in a fluttering shawl was creeping slowly by the railings, staggering as she went. Now and then she stopped and peered back. Once she began to sing in a hoarse voice' (126). Sibyl is a haunting that continues to haunt him all his life and beyond.

The appearance and disappearance of emotive women, on stage and outside is a primitive threatening of the order of time and space. The journey is what is most exquisite. Sibyl realizes she possesses the indestructibility of semantic transference at her disposal. The before-time and after-time work from both ways to save her from the approaching decays of now-time. She mystically progresses through love, deceit, damnation, revival, without having to give up her passions and her childish concoction of fresh dreams and fresh nightmares.

\section{References}

Duggan, Patrick. 2009. Between Aestheticism and Morality in Oscar Wilde's The Picture of Dorian Gray, https://doc.uments.com/g-the-conflict-between-aestheticismand-morality-in-oscar-wildes.pdf, (retrieved 20 May,2020).

Irigaray, Luce. 1977. This Sex Which is Not One (trans. Catherine Porter, and Carolyn Burke). New York, Ithaca: Cornell University Press.

Metz, Christian. 1982. The Imaginary Signifier: Psychoanalysis and the Cinema. Bloomington: Indiana University Press.

Poulet, Georges. 1969. 'Stendhal and Time', in Red and Black. New York: Norton and Co.

Wilde, Oscar. 1991. The Picture of Dorian Gray. London: Wordsworth Editions

Woolf, Virginia. 1953. Mrs Dalloway. New York: Harcourt. 